\title{
Tarsal Bone
}

National Cancer Institute

\section{Source}

National Cancer Institute. Tarsal Bone. NCI Thesaurus. Code C12796.

Any one of the seven bones forming the instep of the foot. 